Jurnal Natur Indonesia 14(1), Oktober 2011: 61-67

ISSN 1410-9379, Keputusan Akreditasi No 65a/DIKTI/Kep./2008

\title{
Inokulasi Fungi Mikoriza Arbuskula (FMA) Indigenus pada Bibit Jahe untuk Pengendalian Penyakit Layu Ralstonia solanacearum ras 4)
}

\author{
Netty Suharti ${ }^{\left({ }^{*}\right)}$, Trimurti Habazar ${ }^{2)}$, Nasril Nasir ${ }^{3)}$, Dachryanus ${ }^{1)}$ dan Jamsari ${ }^{2}$ \\ ${ }^{1}$ Fakultas Farmasi, Universitas Andalas, Padang 25163 \\ ${ }^{2)}$ Fakultas Pertanian, Universitas Andalas, Padang 25163 \\ ${ }^{3)}$ Fakultas Matematika dan Ilmu Pengetahuan Alam, Universitas Andalas, Padang 25163 \\ Diterima 28-12-2010 Disetujui 13-05-2011
}

\begin{abstract}
Bacterial wilt disease caused by Ralstonia solanacearum race 4 is one of factors inhibiting ginger production. The study on Arbuscular Mychorrizae Fungus (AMF) in greenhouse was found could reduce of bacteria wilt disease. Experiment design of research was randomized block design using 8 isolates. The results showed that inoculation of Arbuscular Mychorrhizae Fungus isolated from healthy ginger rhizosphere as biological diseases control agents could reduces disease severity. Four isolate could reduced disease severity up to $100 \%$ and support plant growth and production. As the result the seedling formation increased by 50-150\%, plant height 36.92-87.56\%, the number of leaf $61.94-162.22 \%$ and ginger yield $190.62-400 \%$ respectively, compared to the control.
\end{abstract}

Keywords: Arbuscular Mychorrizae Fungi, ginger, R.solanacearum ras 4

\section{PENDAHULUAN}

Jahe (Zingiber officinale Rosc.) merupakan salah satu tanaman penghasil minyak atsiri dan oleoresin yang sudah lama dimanfaatkan masyarakat untuk bahan rempah dan obat (Ravindran \& Babu 2005; Paimin \& Murhananto 1991). Nilai ekonomi dari jahe terdapat pada rimpangnya yang memiliki khasiat sebagai antioksidan, antiinflamasi, antibakteri dan karminatif(Malu et al. 2009; Hinneburg et al. 2006). Tanaman ini termasuk salah satu komoditi unggulan dalam menggalakkan komoditi non migas, sehingga mendapat perhatian untuk dikembangkan di Indonesia (Suratman et al. 1987; Wattimena 2004).

Produktivitas jahe Indonesia masih rendah dan terjadi penurunan luas panen serta hasil, salah satu penyebabnya adalah penyakit layu bakteri Ralstonia solanacearum ras 4 (Suratman et al. 1987; Annonim 1989; Trubus 1990). Patogen ini sulit dikendalikan, karena dapat bertahan selama satu tahun dalam tanah tanpa kehilangan virulensinya, serta menyerang tanaman pada berbagai fase pertumbuhan (Hayward 1991; Trisilawati 2000). Di Hawai patogen ini dapat menyebabkan kehilangan hasil pada tanaman jahe lebih dari 45\% (Alvarez et al. 2004). Penyakit layu bakteri pada tanaman jahe telah memusnahkan pertanaman jahe di sebagian besar wilayah asia seperti India, Philipina, Thailand dan Indonesia (Elphinstone 2004). Dari Kabupaten Solok sebagai salah satu sentra produksi jahe Sumatera Barat diinformasikan bahwa semenjak tahun 2000 patogen ini telah memusnahkan tanaman jahe secara total (Yusniarti 2005). Dinas perkebunan Kabupaten Solok, komunikasi pribadi).

Pengendalian penyakit tanaman yang disebabkan oleh bakteri perlu mengacu pada konsep Pengendalian Hama Terpadu (PHT). Salah satu komponen dalam PHT adalah pengendalian hayati (Bilogical Control) (Habazar 2001). Salah satu mikroorganisme yang dapat berperan sebagai agensia pengendali hayati yang potensial untuk dikembangkan adalah Fungi Mikoriza Arbuskular (FMA) Indigenus.

Mekanisme yang diduga mendukung peran FMA dalam meningkatkan pertumbuhan dan pertahanan tanaman inang terhadap patogen akar adalah melalui pengurangan eksudat akar, peningkatan pertumbuhan tanaman inang, penimbunan unsur mikro dan produksi metabolit sekunder (Linderman 1994; Pfleger \& Linderman 2000). Akar tanaman jeruk yang dikolonisasi oleh FMA dapat meningkatkan ketahanannya terhadap patogen Phytophthora parasitica karena intensitas serangan berkurang (Campbell 1989). Kolonisasi FMA jenis Glomus sp pada tomat dapat menekan perkembangan penyakit layu fusarium yang disebabkan oleh Fusarium oxysporum f.sp.lycopersici (Reflin 1993), menurunkan intensitas serangan oleh Xanthomonas axonopodis pv. vecatoria (Yusman 2003). Hasil penelitian Yefriwati et al. (2005), menunjukan inokulasi dengan $G$. fasciculatum, G. etunicatum dan Acaulospora sp secara tunggal maupun gabungan dapat meningkatkan ketahanan

\footnotetext{
*Telp: +6281363422766

Email: nettysuharti@yahoo.com
} 
bibit pisang Cavendish terhadap R.solanacearum ras 2 . Aplikasi G. fasciculatum dapat menginduksi ketahanan tanaman kedelai terhadap penyakit pustul bakteri yang disebabkan Xanthomonas campestris pv. glycines (Harmet 1999).

Informasi mengenai kemampuan FMA indigenus dalam pengendalian penyakit layu bakteri pada tanaman jahe masih terbatas dan belum ditemukan isolat FMA spesifik yang berpotensi dalam mengendalikan patogen pada tanaman jahe. Tujuan dari penelitian ini adalah untuk memperoleh isolat Fungi Mikoriza Arbuskula (FMA) indigenus yang mampu mengendalikan penyakit layu bakteri pada tanaman jahe.

\section{BAHANDANMETODA}

Metoda Penelitian. Rancangan yang digunakan adalah Rancangan Acak Kelompok dengan 8 perlakuan dan 6 ulangan. Perlakuan percobaan adalah introduksi 8 isolat FMA indigenus yaitu SLK1, SLK2, SLK3, SLK4, SLK5, SLK6, SLK7, SLK8 dan kontrol pada benih jahe. Setelah tanaman berumur 2 bulan dilakukan inokulasi dengan Ralstonia solanacearum ras 4. Data pertumbuhan dan hasil rimpang jahe dianalisis dengan sidik ragam dan dilanjutkan dengan DNMRT 5\%.

Penelitian ini dilaksanakan di Laboratorium Bakteriologi Jurusan Hama dan Penyakit Tumbuhan, Rumah Kaca, Fakultas Pertanian Unand Padang dari Januari sampai Oktober 2009. Tahapan pelaksanaan adalah sebagai berikut: Isolat FMA indigenus diisolasi dari rizosfir tanaman jahe pada lahan endemik penyakit layu bakteri R. solanacearum ras 4 di Nagari Salayo, Kabupaten Solok (SLK).

Produksi inokulan. Isolat FMA indigenus diperbanyak pada akar sorghum yang ditanam pada pot berisi pasir steril. Setelah berumur dua bulan, bagian atas tanaman dipotong, bagian akar beserta pasir dipanen sebagai sumber inokulan. Sebanyak 200 gr inokulan tersebut dicampurkan dengan $4 \mathrm{~kg}$ pasir steril dimasukkan ke dalam pot besar dan ditanami kecambah jagung. Tanaman dipelihara dan dipupuk dengan $20 \mathrm{ml}$ larutan hara rendah $\mathrm{P}$ dengan konsentrasi $5 \mathrm{~g} / \mathrm{l}$. Setelah berumur 2 bulan bagian atas tanaman jagung dipotong, dibiarkan selama 1 bulan, kemudian akarnya bersama pasir dipanen dan digunakan sebagai sumber inokulan.

Aplikasi isolat FMA dan inokulasi bakteri $\boldsymbol{R}$. solanacearum ras 4. Bibit rimpang jahe dicuci bersih, seberat 50 gr yang memiliki 2-3 mata direndam dalam alkohol $70 \%$ selama 15 menit, dicuci lagi dengan aquades, dikeringkan dan ditanamkan pada tanah dalam polybag yang telah diberi isolat FMA sesuai perlakuan sebanyak $50 \mathrm{~g}$ (dengan kerapatan 100 spora ) per polybag.

Inokulasi bakteri Ralstonia solanacearum. Bibit jahe yang menunjukkan gejala layu dipelihara untuk digunakan sebagai sumber inokulum R.solanacearum ras 4. Batang dan rimpang jahe dipotong, dihancurkan, dilakukan pengenceran sampai $10^{-6}$. Kekeruhan suspensi yang di ukur dengan spektrofotometer dan dibandingkan dengan larutan Mc Farland ( $1 \mathrm{ml} \mathrm{BaCl}_{2} .9 \mathrm{ml} \mathrm{H}_{2} \mathrm{SO}_{4} 1 \%$ ) dengan kerapatannya diperkirakan $10^{8}$ unit pembentuk koloni/ml. Suspensi diinokulasikan sebanyak $20 \mathrm{ml}$ pada akar tanaman jahe yang telah dilukai dengan jarum pentul. Sebanyak $1 \mathrm{ml}$ suspensi dimasukkan kedalam 2 cawan petri dan masing-masing ditambahkan $15 \mathrm{ml}$ media NA dan trypenyl tetrazoliumchlorida (TTC) diinkubasi selama 24-48 jam, diamati koloni yang terbentuk, dimurnikan dengan memindahkan pada media agar miring. Uji konfirmasi untuk memastikan bahwa isolat yang diperoleh adalah $R$. solanacearum dibuat mutan dengan menanam pada media selektif yang mengandung antibiotik kanamycin.

Pengamatan. Peubah yang diamati pada setiap perlakuan adalah sebgai berikut:

1. Saat munculnya anakan pertama dan jumlah anakan yang terbentuk.

2. Periode inkubasi, diamati tiap hari setelah penanaman bibit sampai munculnya gejala serangan yang ditandai dengan menguningnya daun yang masih muda.

3. Kejadian penyakit yang diamati setiap hari, dihitung dengan mengunakan rumus Wang (1998): $\mathrm{P}=\mathrm{a} / \mathrm{b}$ x $100 \%$ dimana :

$\mathrm{P}=$ Persentase serangan layu

$\mathrm{a}=$ jumlah tanaman yang menunjukkan gejala layu/ perlakuan

$\mathrm{b}=$ jumlah tanaman yang diamati/perlakuan

4. Pertumbuhan tanaman

a. Jumlah tunas terbentuk dan saat pertama munculnya tunas, diamati 2 minggu setelah tanam dengan interval waktu 1 minggu.

b. Tinggi tanaman, diamati mulai tanaman berumur 2 minggu setelah tanam dengan interval waktu 1 minggu, dengan mengukur tanaman dari pangkal sampai ujung batang.

c. Jumlah daun, dihitung mulai bibit tanaman berumur 2 minggu setelah tanam, sampai akhir pengamatan (4 bulan setelah tanam).

5. Kolonisasi FMA pada akar tanaman jahe 
Pengamatan kolonisasi pada akar tanaman jahe dilakukan pada 3 minggu, 1 bulan dan 2 bulan setelah inokulasi. Akar diambil, dicuci dengan air mengalir, dikering anginkan, dipotong-potong sepanjang $1 \mathrm{~cm}$ dan dimasukkan kedalam tabung reaksi, ditambah $\mathrm{KOH}$ 5\% dipanaskan selama 15 menit, dibilas dengan aquades, ditambahkan $\mathrm{KCl}$ $2 \%$ selama 10 menit dan dicuci dengan aqudes. Selanjutnya dilakukan pewarnaan dengan Triphan blue di dalam gliserin dan asam laktat selama 24 jam, kemudian pewarna dibuang dan diganti dengan yang baru tanpa Triphan blue. Sepuluh potong akar yang telah direndam dalam pewarnaan di susun pada objek gelas, ditutup dengan cover gelas dan diamati dibawah mikroskop. Presentase koloni FMA dihitung berdasarkan bidang pandang metode slide (Giovannetti \& Mosse 1980). Bidang pandang yang menunjukkan kolonisasi diberi tanda (+) dan yang tidak ditemukan tandatanda kolonisasi diberi tanda (-). Persentase kolonisasi oleh FMA dihitung sebagai berikut :

$$
\text { persentase }=\frac{\operatorname{total}(+)}{\operatorname{total}(+) \operatorname{dan}(-)} \times 100 \%
$$

Populasi bakteri $R$. solanacearum pada akar tanaman jahe diisolasi dan dihitung pada 1, 3, 6 dan 9 hari setelah inokulasi (hsi). Bagian akar diambil sepanjang $2 \mathrm{~cm}$, dicuci, disterilisasi permukaan dengan alkohol $70 \%$ dan dibilas dengan akuades steril lalu dihancurkan. Suspensi diencerkan sampai $10^{-6}$, kemudian ditumbuhkan pada media tripenyl tetrazolium chlorida (TZC) dan diinkubasi pada suhu kamar pada $32^{\circ} \mathrm{C}$ selama 48 jam. Populasi bakteri dihitung dengan colony counter.

Penghitungan koloni bakteri menggunakan rumus Klement et al. (1990) :

$\mathrm{JB}=\mathrm{A} \times \mathrm{B}$

$\mathrm{JB}=$ Jumlah bakteri

A = Jumlah koloni bakteri

$\mathrm{B}=$ Faktor Pengenceran

Isolasi bakteri penyebab penyakit. Untuk meyakinkan bahwa tanaman yang menunjukkan gejala layu yang ditemukan di lapangan disebabkan oleh $R$. solanacearum ras 4, dilakukan isolasi bakteri dari rimpang tanaman jahe yang menunjukkan gejala layu. Permukaan rimpang jahe didisinfeksi dengan larutan alkohol 70\%. Setelah itu dipotong dengan ukuran $1 \mathrm{~cm}$ dan digrinder dalam lumpang dan dimasukkan ke dalam Phospat Buffer Salin (PBS) 0,02 M pH 7,2 dan divortex. Suspensi tersebut digoreskan masing-masing dalam media NA (Nutrien Agar) dan media TTC (tripenyl tetrazolium chlorida) dan diinkubasikan pada suhu $32^{\circ} \mathrm{C}$. Pengamatan dilakukan terhadap koloni bakteri yang tumbuh 48-72 jam setelah isolasi. Koloni bakteri yang diduga sebagai penyebab penyakit layu bakteri pada jahe kemudian diuji gram dengan menggunakan $\mathrm{KOH} 3 \%$ dan uji, uji patogenesitas pada tanaman jahe klon gajah yang berumur 2 bulan. Identifikasi bakteri mengacu pada Schaad et al. (2001).

\section{HASIL DAN PEMBAHASAN}

Identifikasi tanaman yang terinfeksi penyakit layu bakteri di lapangan. Hasil pengamatan memperlihatkan bahwa tanaman jahe yang terinfeksi penyakit layu di lapangan telah mencapai $80 \%$, dengan gejala daun yang menguning dimulai dari titik tumbuh, gejala lanjut daundaun yang menguning telah terlepas dari batang semu (pseudostem). Jika rimpang dipotong, terlihat bagian dalam yang lunak, berwarna coklat dan berbau busuk karena adanya eksudat bakteri yang keluar dari batang semu dan rimpang. Gejala ini sesuai dengan gejala penyakit layu bakteri pada jahe yang dikemukakan oleh Supriadi (2000), dan Schaad et al. (2001).

Isolasi dan identifikasi bakteri Ralstonia solanacearum ras 4. Hasil isolasi terhadap bakteri dari rimpang tanaman jahe yang terserang penyakit layu, ditemukan koloni bakteri yang memiliki ciri-ciri berwarna putih susu pada media NA dan bewarna merah muda dengan media TTC, bentuk koloni mucoid, viscid (lengket), dengan pertumbuhan yang lambat. Ciri-ciri tersebut sesuai dengan ciri-ciri koloni Ralstonia solanacearum ras 4 yang didiskripsikan oleh Schaad et al. (2001).

Hasil uji Gram menunjukkan bahwa koloni bakteri yang ditemukan adalah kelompok Gram negatif. Uji patogenesitas menunjukkan bahwa bakteri tersebut bersifat patogen dengan adanya klorosis dan layu pada tanaman jahe setelah disuntikkan suspensi bakteri. Gejala layu tanaman jahe, seperti pada gejala serangan $R$. Solanacearum ras 4 , yang meyakinkan bahwa koloni bakteri merupakan koloni $R$. Solanacearum ras 4.

Kolonisasi FMA Pada Akar Tanaman Jahe. Semua akar jahe terkolonisasi oleh FMA dengan persentase kolonisasi yang bervariasi, kecuali tanaman kontrol. Kolonisasi pada akar tanaman jahe telah terjadi pada 3 minggu setelah tanam yaitu 20-40\%, dengan terbentuknya arbuskula, hifa internal dan hifa eksternal. Persentase kolonisasi akar tanaman jahe oleh FMA meningkat sejalan dengan meningkatnya umur tanaman jahe dan kolonisasi tertinggi terjadi pada saat 2 bulan setelah tanam yaitu 80-90\%. Hal ini menunjukkan bahwa inokulum yang digunakan kompatibel dengan tanaman jahe, sehingga mampu membentuk arbuskular, vesikula, hifa internal dan 
hifa eksternal yang berperan dalam penyerapan hara dan air untuk meningkatkan kebugaran tanaman (Bolan 1991), dan ketahanan tanaman terhadap penyakit (Vigo et al. 2000). Ketahanan tanaman jahe terhadap serangan R.solanacearum ras 4, disebabkan akar yang telah terkolonisasi FMA akan menghasilkan senyawa kimia yang bersifat sebagai antimikroba sehingga dapat melindungi perakaran tanaman terhadap patogen.

Menurut Brundrett (1996), struktur FMA dapat berfungsi sebagai pelindung biologi terhadap patogen akar karena (1) Terdapatnya selaput hifa yang berfungsi sebagai penghalang masuknya patogen, (2) mikoriza menggunakan hampir semua kelebihan karbohidrat dan eksudat lainnya sehingga tercipta lingkungan tidak sesuai bagi perkembangan patogen, (3) FMA dapat mengeluarkan antibiotik yang dapat mematikan atau menghambat pertumbuhan patogen, dan (4) Akar tanaman yang sudah terkolonisasi FMA tidak dapat atau sulit dipenetrasi oleh patogen karena patogen harus berkompetisi dengan FMA terlebih dahulu. Inokulasi FMA dapat mempengaruhi respon fisiologis dan biokimia, melalui peningkatan aktivitas enzim dan kandungan senyawa kimia yang menghambat perkembangan patogen (Ming \& Hui 1994; Pfleger \& Linderman 2000).

Kejadian penyakit pada bibit jahe yang diinokulasi dengan FMA menunjukkan bahwa 4 perlakuan isolat memiliki efektifitas masa inkubasi $100 \%$ dan 4 perlakuan isolat lainnya masih terserang dengan efektifitas 55,67-83,34\%. Bibit jahe yang diintroduksi dengan FMA isolat SLK1, SLK3, SLK5, SLK8, tidak memperlihatkan gejala layu sampai akhir pengamatan (4 bulan setelah inokulasi). Inokulasi FMA isolat SLK2, SLK4, SLK6, dan SLK7 pada tanaman jahe tidak mampu mencegah timbulnya gejala layu dengan masa inkubasi yang berbeda yaitu 7,50-14 hari, persentase tanaman layu 16,66-33,33\%, lama kematian 31,67- 45,33 hari setelah inokulasi. Namun masa inkubasi paling cepat terdapat pada tanaman kontrol yaitu 4,16 hari setelah inokulasi, dengan tanaman layu mencapai $100 \%$ dan lama kematian 14,67 hari setelah inokulasi (Tabel 1).

Untuk melihat kemampuan isolat FMA dalam mengendalikan penyakit layu bakteri dilakukan pelacakan populasi $R$. solanacearum ras 4 yang terdapat pada akar tanaman jahe pada 1, 3, 6 dan 9 hari setelah inokulasi (Gambar 1).

Setelah dilakukan pengamatan terhadap populasi $R$ solanacearum ras 4 pada akar tanaman jahe, ternyata seluruh tanaman terinfeksi oleh patogen tersebut, akan tetapi tidak semua tanaman memperlihatkan gejala. Terdapat variasi kerapatan populasi bakteri $R$ solanacearum ras 4 pada tanaman jahe yang diinokulasi FMA. Pada pengamatan 1 hari setelah inokulasi terdapat variasi populasi $R$. solanacearum ras 4 pada akar tanaman jahe. Tanaman jahe yang diinduksi dengan FMA isolat SLK1 dan SLK3 terjadi penurunan populasi $R$. solanacearum ras 4 pada 3 sampai 9 hsi. Tanaman yang diinokulasi dengan FMA isolat SLK2, SLK4 SLK6, SLK7 dan SLK8 terjadi peningkatan populasi R.solanacearum ras 4 pada 3 hsi, tetapi pada 6 dan 9 hsi, populasi patogen kembali menurun dan populasi $R$. solanacearum ras 4 tertinggi ditemukan pada tanaman kontrol.

Mekanisme FMA dalam mengendalikan berbagai jenis patogen dapat terjadi secara langsung berupa kompetisi dan antibiosis dan secara tidak langsung melalui induksi ketahanan. Mekanisme secara langsung disebabkan pertumbuhan propagul infektif dari FMA yang dapat menghalangi patogen pada akar tanaman (Kobayashi \& Branch 1991). Mekanisme tidak langsung adalah melalui respon fisiologis dan biokimia dengan terjadinya perubahan aktivitas enzim dan peningkatan senyawa kimia yang menghambat perkembangan patogen (Pfleger \& Linderman 2000).

Pertumbuhan Tanaman Jahe yang diintroduksi dengan FMA dan diinokulasi dengan $R$. solanacearum ras Tabel 1 Kejadian penyakit layu pada tanaman jahe yang diinroduksi FMA dan diinokulasi $R$. Solanacearum ras 4

\begin{tabular}{lccc}
\hline Isolat FMA & \multicolumn{3}{c}{ Kejadian penyakit } \\
\cline { 2 - 4 } & $\begin{array}{c}\text { Masa inkubasi } \\
(\text { hari) }\end{array}$ & $\begin{array}{c}\text { Tanaman layu } \\
(\%)\end{array}$ & $\begin{array}{c}\text { Lama kematian } \\
\text { (hari) }\end{array}$ \\
\hline SLK1 & $120^{*}$ & 0 & $*$ \\
SLK2 & 14,00 & 16,66 & 31,67 \\
SLK3 & $120^{*}$ & 0 & $*$ \\
SLK4 & 9,0 & 33,33 & 45,33 \\
SLK5 & $120^{*}$ & 0 & $*$ \\
SLK6 & 7,50 & 16,66 & 45,33 \\
SLK7 & 9,83 & 33,33 & 39,33 \\
SLK8 & $120^{*}$ & 0 & $*$ \\
Kontrol & 4,16 & 100 & 14,67 \\
\hline Keterangan $*$ tidak ada tanaman terserang penyakit layu
\end{tabular}

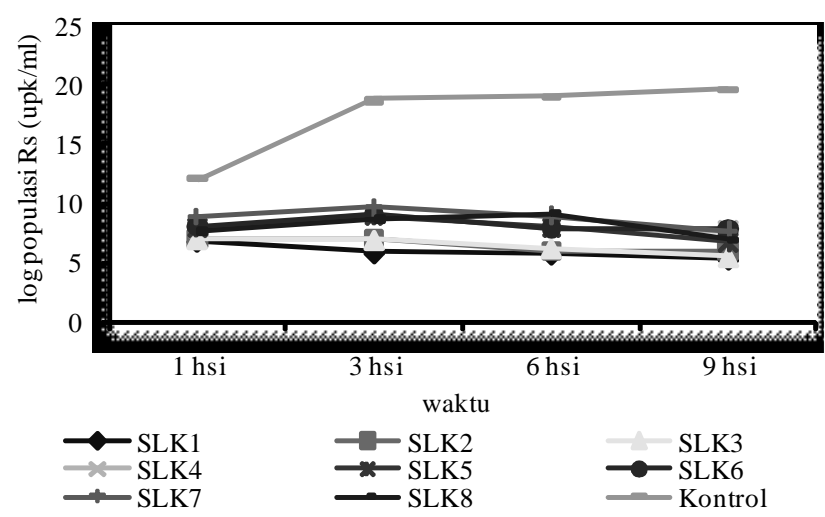

Gambar 1 Logaritma populasi R.solanacearum ras 4 pada akar tanaman jahe yang diintroduksi dengan FMA. SLK = isolat Solok, hsi $=$ hari setelah inokulasi 
4. Inokulasi FMA indigenus pada tanaman jahe berpengaruh terhadap pertumbuhan tanaman. Pengamatan terhadap pertumbuhan tanaman jahe yang diinokulasii dengan FMA berupa jumlah anakan, tinggi tanaman dan jumlah daun disajikan pada Tabel 2.

Hasil Analis sidik ragam terhadap pertumbuhan tanaman jahe menunjukkan perbedaan yang nyata antara tanaman yang diinokulasi dengan isolat FMA indigenus dibanding kontrol $(\mathrm{P}<0,05)$. Tanaman jahe yang diinokulasi dengan FMA isolat SLK1 menghasilkan pertumbuhan tertinggi yaitu jumlah anakan 5 buah (peningkatan 150\%), tinggi tanaman $72,83 \mathrm{~cm}(87,56 \%)$ dan jumlah daun 16,83 lembar $(162,22 \%)$ sedangkan tanaman kontrol hanya menghasilkan 2 anakan, tinggi tanaman $38,83 \mathrm{~cm}$ dan jumlah daun 7,2 helai. Introduksi isolat FMA indigenus pada tanaman jahe juga mampu meningkatkan produksi rimpang dibanding kontrol (Tabel 3).

Aplikasi FMA pada bibit juga berpengaruh terhadap hasil rimpang tanaman jahe. Tanaman jahe yang diintroduksi Isolat FMA indigenus SLK 1 menghasilkan rimpang dan tajuk tanaman lebih banyak dengan peningkatan masingmasing 400\% dan 598,30\%, dibanding kontrol. Disamping mampu mengendalikan patogen tanaman, FMA juga memiliki peran sebagai Plant Growth Promoting Fungi (PGPF), sehingga mampu meningkatkan pertumbuhan tanaman melalui peningkatan penyerapan air dan hara yang terlarut didalamnya, terutama unsur $\mathrm{P}$ yang dibutuhkan untuk pertumbuhan tanaman (Bolan 1991).

Hasil penelitian ini menunjukkan isolat FMA indigenus rizosfir tanaman jahe sehat dari lahan endemik yang diintroduksi pada bibit jahe mampu menahan perkembangan penyakit layu bakteri yang disebabkan $R$. solanacearum ras 4 dengan kemampuan yang bervariasi. Apliksi FMA indigenus juga mampu meningkatkan pertumbuhan dan produksi tanaman jahe, yang menunjukkan bahwa, isolat FMA ini sudah beradaptasi dengan lingkungan sehingga mampu menghambat serangan patogen dan merebut nutrisi dari tanah sehingga banyak tersedia untuk menunjang pertumbuhan tanaman (Bolan 1991).

Pada tanaman yang terserang, gejala serangan dapat diamati dari bagian luar tanaman jahe yaitu dengan mulai menguningnya daun yang masih muda yang diikuti dengan daun yang sudah tua serta lepasnya tangkai daun dari batang semu. Hasil pengujian terhadap 8 isolat FMA indigenus dari rizosfir tanaman jahe sehat pada lahan endemik telah teresleksi 4 isolat yang mampu meningkatkan ketahanan tanaman jahe terhadap $R$. solanacearum ras 4 , sampai akhir pengamatan 4 minggu setelah inokulasi (msi).

Penelitian ini menunjukan bahwa pengujian kemampuan agens hayati dalam mengendalikan patogen tanaman lebih

Tabel 2 Pertumbuhan tanaman jahe setelah diinokulasi dengan FMA Indigenus dan R.solanacearum ras 4

\begin{tabular}{|c|c|c|c|c|c|c|c|}
\hline \multirow[t]{2}{*}{ No. } & \multirow[t]{2}{*}{ Isolat FMA } & \multicolumn{6}{|c|}{ Pertumbuhan tanaman jahe setelah diintroduksi dengan FMA 14 mingu setelah inokulasi } \\
\hline & & $\begin{array}{c}\text { Jumlah anakan } \\
\text { (buah) }\end{array}$ & $\begin{array}{c}\text { Peningkatan } \\
(\%)\end{array}$ & $\begin{array}{l}\text { Tinggi Tanaman } \\
(\mathrm{cm})\end{array}$ & $\begin{array}{c}\text { Peningatan } \\
(\%)\end{array}$ & $\begin{array}{c}\text { Jumlah daun } \\
\text { (helai) }\end{array}$ & $\begin{array}{c}\text { Peningkatan } \\
(\%)\end{array}$ \\
\hline 1 & SLK1 & $5^{\mathrm{ab}}$ & 150 & $72,83^{\mathrm{d}}$ & 87,56 & $16,83^{\mathrm{d}}$ & 162,22 \\
\hline 2 & SLK2 & $3^{\mathrm{a}}$ & 50 & $66,71^{\mathrm{c}}$ & 71,83 & $16^{\mathrm{d}}$ & 161,94 \\
\hline 3 & SLK3 & $3^{\mathrm{a}}$ & 50 & $52,5^{\mathrm{b}}$ & 36,96 & $15,5^{\mathrm{cd}}$ & 156,88 \\
\hline 4 & SLK4 & $5^{\mathrm{ab}}$ & 150 & $65,55^{\mathrm{c}}$ & 68,81 & $11,66^{\mathrm{bc}}$ & 61,94 \\
\hline 5 & SLK5 & $3^{\mathrm{a}}$ & 50 & $58,46^{\mathrm{c}}$ & 52,52 & $13,5^{\mathrm{c}}$ & 87,50 \\
\hline 6 & SLK6 & $4^{\mathrm{a}}$ & 100 & $52,43^{\mathrm{b}}$ & 36,92 & $14,5^{\mathrm{c}}$ & 106,57 \\
\hline 7 & SLK7 & $5^{\mathrm{ab}}$ & 150 & $63,05^{\text {bc }}$ & 64,49 & $14,66^{\mathrm{c}}$ & 103,61 \\
\hline 8 & SLK8 & $5^{\mathrm{ab}}$ & 150 & $59,95^{\mathrm{c}}$ & 56,40 & $13,5^{\mathrm{c}}$ & 87,50 \\
\hline 9 & Kontrol & $2^{\mathrm{a}}$ & 0 & $38,83^{\mathrm{a}}$ & 0,00 & $7,2^{\mathrm{a}}$ & 0 \\
\hline
\end{tabular}

Angka-angka pada kolom yang sama yang diikutioleh huruf kecil yang sama tidak

berbeda nyata menurut Uji Jarak Berganda Duncan Pada taraf nyata 5\%

Tabel 3 Berat basah rimpang dan bagian atas tanaman jahe yang ditanam di Rumah Kaca setelah diinokulasi dengan isolat FMA indigenus

\begin{tabular}{|c|c|c|c|c|c|c|c|}
\hline \multirow[t]{2}{*}{ No. } & \multirow[t]{2}{*}{ Isolat } & \multicolumn{6}{|c|}{ Hasil Tanaman Jahe (7bst) } \\
\hline & & $\begin{array}{c}\text { Rimpang } \\
(\mathrm{g})\end{array}$ & $\begin{array}{c}\text { Peningkatan } \\
(\%)\end{array}$ & $\begin{array}{l}\text { Tajuk } \\
(\mathrm{g})\end{array}$ & Peningkatan (\%) & $\begin{array}{l}\text { Total } \\
(\mathrm{g})\end{array}$ & $\begin{array}{c}\text { Peningkatan } \\
(\%)\end{array}$ \\
\hline 1 & SLK1 & $160,00^{f}$ & 400,00 & $82,40^{\mathrm{e}}$ & 598,30 & $242,40^{\mathrm{e}}$ & 453,42 \\
\hline 2 & SLK2 & $116,50^{\mathrm{d}}$ & 264,06 & $54,00^{\mathrm{c}}$ & 442,40 & $180,50^{\mathrm{d}}$ & 312,10 \\
\hline 3 & SLK3 & $130,00^{\mathrm{ef}}$ & 368,75 & $58,00^{\mathrm{cd}}$ & 391,00 & $188,00^{\mathrm{d}}$ & 329,22 \\
\hline 4 & SLK4 & $104,00^{\mathrm{cd}}$ & 321,87 & $66,5^{\mathrm{de}}$ & 463,00 & $190,50^{\mathrm{d}}$ & 334,93 \\
\hline 5 & SLK5 & $122,50^{\mathrm{de}}$ & 301,56 & $43,5^{\text {bc }}$ & 268,60 & $167,00^{\mathrm{c}}$ & 281,27 \\
\hline 6 & SLK6 & $114,00^{\mathrm{d}}$ & 243,75 & $38,0^{\mathrm{b}}$ & 222,00 & $152,00^{\mathrm{b}}$ & 247,03 \\
\hline 7 & SLK7 & $94,00^{\mathrm{bc}}$ & 200,00 & $55,5^{\mathrm{c}}$ & 370,34 & $149,50^{\mathrm{b}}$ & 241,32 \\
\hline 8 & SLK8 & $95,00^{\mathrm{bc}}$ & 190,62 & $52,5^{\mathrm{c}}$ & 344,91 & $147,50^{\mathrm{b}}$ & 236,76 \\
\hline 9 & Kontrol & $32,00^{\mathrm{a}}$ & 0 & $11,80^{\mathrm{a}}$ & 0 & $43,80^{\mathrm{a}}$ & 0 \\
\hline
\end{tabular}

Angka yang diikuti oleh huruf kecil yang sama pada kolom yang sama tidak berbeda nyata menurut uji Jarak berganda Duncan pada taraf nyata $5 \%$ 
baik secara in planta, karena kompleksnya mekanisme agens hayati dalam mengendalikan patogen tanaman, ada yang bersifat langsung terhadap patogen seperti kompetisi, hiperparasit, antibiosis, lisis, ada juga yang bersifat tidak langsung, seperti melalui peningkatan ketahanan/kebugaran tanaman sehingga dapat menghambat perkembangan patogen (induksi ketahanan) dan peningkatan pertumbuhan dan produksi tanaman serta aman terhadap lingkungan.

\section{SIMPULAN}

Isolat FMA hasil isolasi mampu menekan perkembangan penyakit layu bakteri yang disebabkan oleh $R$. solanacearum ras 4 pada tanaman Jahe dengan efektifitas penurunan penyakit yang bervariasi. Sebanyak 4 isolat FMA yang diinokulasikan pada bibit mampu meningkatkan ketahanan tanaman jahe terhadap penyakit layu $R$ solanacearum ras 4 mencapai 100\%, sedangkan 4 isolat memiliki kemampuan yang bervariasi dalam menekan penyakit layu bakteri yaitu $66,47-83,34 \%$.

Inokulasi FMA pada bibit tanaman jahe juga mampu meningkatkan pertumbuhan dan produksi jahe, berbeda nyata dibanding kontrol $(\mathrm{P}<0,05)$ dengan peningkatan pembentukkan tunas $150 \%$, tinggi tanaman $87,56 \%$,jumlah daun $162,22 \%$, hasil rimpang $400 \%$ dan tajuk tanaman $598,30 \%$.

\section{UCAPANTERIMAKASIH}

Tulisan ini merupakan hasil Penelitian yang dibiayai Direktorat Penelitian Pengabdian Kepada Masyarakat Dirjen Pendidikan Tinggi, Departemen Pendidikan Nasional Indonesia melalui program Hibah Bersaing dengan kontrak nomor: 005/SP2H/PP/DP2M/III/2009. Dengan ini penulis mengucapkan terima kasih atas dukungan dana yang telah diberikan, sehingga penelitian ini dapat terlaksana.

\section{DAFTAR PUSTAKA}

Annonim. 1989. Bididaya jahe dan pemasarannya. departemen pertanian indonesia

Alvarez, M.A., Trotter, K.J., Swafford, M.D. \& Brestecky, J.M. 2004. Characterization and detection of ralstonia solanacearum strains causing bacterial wilt of ginder in hawaii Hal 471-477. In; Bacterial wilt disease and the $R$. solanacearum species complex. C. Allen, P. Prior. A.C. Hayward. Eds. APS Press St Paul, Minnesota USA.

Bolan, N.S. 1991. A critical Review on the Role of Mycorrhyzal fungi in the Uptake of Phosphorus by Plant. Plant and Soil 134: 189-207.

Brundrett, M., Bougher, N., Dell, B, Grove, T. \& Malajczuk, N. 1996. Working With Micorrhyzas in Forestry and agriculture. Aciar. Canberra.

Campbell, R. 1989. Biological Control of Microbial Plants Pathogens. Cambridge University Press. Cambridge.
Elphinstone, J.G., Prio, C.P. \& Hayward, A.C. 2004. In Allen, Bacterial Wilt Disease and the Ralstonia solanacearum Species Complex. The American Phytopatholcal Society. St Paul, Minnesota.

Giovannetti, M. \& B. Mosse. 1980. An evaluation technique for measuring vesicular arbuscular mycorrhyzal infection in root. New Phytol 84: 489-500.

Habazar, T. 2001. Aspek Imunisasi Dalam Pengendalian Penyakit Tanaman Secara Hayati. Orasi Ilmiah Pada Rapat Senat Terbuka Fakultas Pertanian Universitas Andalas dalam Rangka Dies Natalis ke-47 30 November 2001 Padang.

Hayward, A.C. 1991. Biology and epidemiology of bacterial wilt caused by P. solanacearum Annu Rev. Phytopathol 29: 65-87.

Harmet. 1999. Peranan glomus fasciculatum dan pupuk fosfor dalam meningkatkan ketahanan tanaman kedelai terhadap penyakit pustul bakteri (xanthomonas sp). Universitas Andalas Padang.

Hinneburg, I., Damien, H.J. \& Hiltunen, R. 2006. Antioxidant activity of selected culinary herbs and spices. Food chemistry 97: $122-129$

Klement, Z., Rudolph, K. \& Sands, D.C. 1990. Inokulation of plant tissue. methods in phytobacteriology. budapest: akademiae kiado.

Kobayashi, N. \& Branch, V. 1991. Biological control of soil born desease with.

Linderman, R.G. 1994. Role of VAM Fungi in Biocontrol. Di dalam Pfleger and Linderman (ed). Mycorrhizae and Plant Health. APS Press. The American Phytopathological Society. St Paul. Minnosota.

Malu, P.S., Obochi, O.G, Tawo, N.E. \& Nyong, E.B. 2009. Antibacterial activity and medicinal properties of ginger (zingiber oficinale). Global Journal of Pure and Applied Science.

Ming, T. \& Hui, C. 1994. The effect of vesicular arbuscular mycorrhyzas on resistance of poplar to a cancer fungus (dothiorella gregaria). In Brundett et al. 1994. Mycorrhyzas for plantation forestry in asia. proceeding of an international symposium and workshop kaiping, guangdong. china.

Paimin, F.B. \& Murhananto. 1991. Budidaya, pengolahan dan perdagangan jahe. penebar swadaya. Jakarta.

Pfleger, L.F. \& Linderman, R.G. 2000. Mycorrhizae and Plant Health. APS Press. The American Phytopathological Society. St Paul. Minnosota.

Ravindran, P.N. \& Babu, K.N. 2005. Ginger the genus zingiber CRP Press. New York.

Reflin. 1993. Pengaruh inokulasi jamur MVA dan fusarium f.sp iycopersici terhadap infeksi jamus fusarium dan pertumbuhan tanaman tomat. Program Pascasarjana Universitas Gadjahmada. Yogyakarta.

Schaad, N.W., Jones, J.B, \& Chun, W. 2001. Laboratory Guide for Identification of Plant. Pathogenic Bacteria. St Paul: The American Phytopatology Society.

Supriadi. 2000. Penyakit Layu Bakteri ( $R$. solanacearum) Pada Tumbuhan Obat dan Strategi Penanggulangannya. Balai Penelitian Tanaman Rempah dan Obat Bogor.

Suratman, Djauhari, E., Rachmat \& Sudiarto. 1987. Pedoman bercocok tanam jahe (Zingiber officinale Rosc). Balai Penelitian Tanaman Rempah dan Obat. Bogor.

Trisilawati, O. 2000. Pengaruh Cendawan Mikoriza Arbuskula Terhadap Produksi Dua Klon Jahe. Prosiding Seminar Nasional Mikoriza I. Departemen Kehutanan dan Perkebunan. Indonesia.

Trubus. 1990. Jahe Gajah Lebih Untung Kalau Dipanen Muda Peluang Bisnis. Majalah Pertanian Edisi Maret 1990. No. 244 Th XXI. 4-5.

Vigo, C., Norman, J.R. \& Hooker, J.E. 2000. Biokontrol of the Phatogen Phytopthora parasitica by arbuscular mycorrhizal fungi in roots. Physiologia Plantarum 125: 393-404.

Wang, J.F. 1998. Basic protocol for conducting research on tomato bacterial wilt cause by ralstonia solanacearum. shanhua; Asia Vegetable Research and Development Center.

Wattimena, GA. 2004. Biotechnology for Sustainable agriculture Development. Makalah pada Pelatihan Peningkatan SDM 
Perguruan Tinggi Dalam Pengembangan Sistim Pertanian Berkelanjutan. Universitas Andalas Padang.

Yefriwati., Habzar, T. \& Reflin, I., Muas. 2005. Aplikasi beberapa jenis Cendawan Mikoriza Arbuskula (CMA) dalam meningkatkan ketahanan bibit pisang terhadap serangan penyakit layu bakteri ralstonia solanacearum ras 2. Seminar dan Workshop Asosiasi Mikoriza Indonesia. Jambi Indonesia
Yusman. 2003. Uji Kemampuan beberapa jenis cendawan mikoriza arbuskula dalam menginduksi ketahanan tanaman tomat terhadap penyakit bercak bakteri (Xanthomonas campestris pv. vesicatoria). Universitas Andalas Padang. 